\title{
The Impress of Memory on the Postmodern Self in Audre Lorde Bell Hooks and Rebecca Walker
}

\author{
Prof. Assoc. Dr. Tidita Abdurrahmani \\ PhD. Karl Franzens Universitaet Graz, \\ Shkolla e Lartë Hëna e Plotë Bedër, Tiranë
}

\begin{abstract}
The question of Self and memory is inextricably linked to the question of the representation and representability as well as to the uniqueness or iterability of the sense of the Self. Criticisms through the times suggest thinking of the sense of Self in terms of one's memory for it--not how faithfully you represent yourself, but rather how accurately you remember your past Self and how much you know about your present Self. Memory is the key element in determining the production of an autobiographical work, it is the author's memory and his sense of Self which determines how accurately he will transpose his life in front of us and correspondingly the one that decides whether autobiography will take the form of a memoir, a semi-fictional autobiography, or a completely fictionalized version of one's life. The relationship between Self and memory has initially been considered by John Locke in his "Essay Concerning Human Understanding"(1698). In his view, a person's identity comprises of whatever a person can remember from his or her past. Consequently, what the person does not remember is not part of his identity. Differing from the other critics, Locke believed that identity and selfhood have nothing to do with continuity of the body, they are rather an extension of memory. The paper delves into the postmodern autobiographical writings of three women-of -color including Audre Lorde, bell hooks and Rebecca Walker. The autobiographies in this study share the arrangement of events in the form of quilts made of accidentally stitched patches, the presentation of life as a fictional narrative and the treatment of the forgotten past as a remembrance and a revisiting. While Audre Lorde s and bell hooks accounts bring an emphasis on myth,(hooks on the construction of a dreamscape and Lorde on the arrangement of the psychological quilt of life), Rebecca Walker asserts that wishful forgetting and the conditioned amnesiac status contribute to the preservation of the fluid character of memory, its organization into dualities and the increased impermanence of the autobiographical account. The reliability of memory, together with the accuracy of life writing determines the classification of a narrative as memoir, autobiography or fictional autobiography. The autobiography criticism corpora are the ones to question the mnemonic truth and the reconciliation of the forces of signification.
\end{abstract}

Keywords: Impress Memory Postmodern Audre Lorde Bell Hooks Rebecca Walker 